Check for updates

Cite this: RSC Adv., 2018, 8, 17224

\title{
Water-soluble cyclometalated platinum(II) and iridium(III) complexes: synthesis, tuning of the photophysical properties, and in vitro and in vivo phosphorescence lifetime imaging $\dagger$
}

Anastasia I. Solomatina, (D) a Shih-Hao Su, ${ }^{\text {b }}$ Maria M. Lukina, ${ }^{c}$ Varvara V. Dudenkova, ${ }^{c}$ Vladislav I. Shcheslavskiy, ${ }^{d}$ Cheng-Ham Wu, ${ }^{b}$ Pavel S. Chelushkin, (D) ${ }^{a}$

$\mathrm{Pi}-$ Tai Chou, (D) ${ }^{* b}$ Igor O. Koshevoy (D) ${ }^{\mathrm{e}}$ and Sergey P. Tunik (D) ${ }^{* a}$

\begin{abstract}
This paper presents synthesis and photophysical investigation of cyclometalated water-soluble Pt(I) and Ir(III) complexes containing auxiliary sulfonated diphosphine (bis(diphenylphosphino)benzene (dppb), $\mathrm{P}^{\wedge} \mathrm{P}^{*}$ ) ligand. The complexes demonstrate considerable variations in excitation (extending up to $450 \mathrm{~nm}$ ) and emission bands (with maxima ranging from ca. 450 to ca. $650 \mathrm{~nm}$ ), as well as in the sensitivity of excited state lifetimes to molecular oxygen (from almost negligible to more than 4-fold increase in degassed solution). Moreover, all the complexes possess high two-photon absorption cross sections (400-500 GM for Pt complexes, and 600-700 GM for Ir complexes). Despite their negative net charge, all the complexes demonstrate good uptake by HeLa cells and low cytotoxicity within the concentration and time ranges suitable for two-photon phosphorescence lifetime (PLIM) microscopy. The most promising complex, [(ppy) ${ }_{2} \operatorname{lr}($ sulfo-dppb)] (Ir1*), upon incubation in HeLa cells demonstrates two-fold lifetime variations under normal and nitrogen atmosphere, correspondingly. Moreover, its in vivo evaluation in athymic nude mice bearing HeLa tumors did not reveal acute toxicity upon both intravenous and topical injections. Finally, Ir1* demonstrated statistically significant difference in lifetimes between normal tissue (muscle) and tumor in macroscopic in vivo PLIM imaging.
\end{abstract}

Received 29th March 2018 Accepted 29th April 2018

DOI: $10.1039 / \mathrm{c} 8 \mathrm{ra02742k}$

rsc.li/rsc-advances emitters from commonly used fluorescent probes and pave the way for their advanced application in imaging experiments. The lifetime in microsecond domain allows discrimination of the probe emission from background fluorescence and other shorttime luminescent signals using time-resolved techniques. This considerably increases image resolution in luminescence microscopy and lowers detection threshold in sensing experiments. ${ }^{1,4,11,12}$ As a result, advanced sensing platforms were developed to recognize various biologically relevant analytes, including (but not limited to) detection of cyanide ions, ${ }^{13}$ biothiols $^{14}$ (including thiourea ${ }^{15}$ ), $\beta$-galactosidase, ${ }^{16}$ dopamine receptor, ${ }^{17}$ or inhibitor of tumor necrosis factor- $\alpha .{ }^{18}$ Moreover, the sensitivity of emission parameters (intensity and lifetime) to oxygen concentration makes possible mapping of oxygen concentration in in vitro and in vivo experiments, ${ }^{19,20}$ including quantitative measurements with the use not only emission intensity but also phosphorescence lifetime imaging (PLIM) techniques, ${ }^{21-25}$ which provides considerably higher precision in oxygen biodistribution mapping. This turns traditional luminescence imaging into the instrument, which allows for functional analysis of physiological status of the targeted objects. For example, it is well known that growing tumors intensively consume oxygen and hence induce hypoxia in these tissues. ${ }^{26,27}$ 
Application of suitable phosphorescent probes for oxygen content analysis gives valuable information, which is helpful for tumor localization and tracking its development and heterogeneity $^{28}$ and even control of drug effect onto the tumor state. ${ }^{19}$ Oxygen is one of the major exogenous compounds in aerobic biological systems and any deviation from "normoxia state" indicates crucial changes in physiological status of the cells and organs studied. The oxygenation mapping with phosphorescent probes has found diverse utilization in various medical research such as oncology (see above), determination of local $\mathrm{O}_{2}$ concentration in bone marrow, ${ }^{22}$ retina, ${ }^{29}$ and live brain, ${ }^{30,31}$ tomographic oxygen mapping at the macroscopic level ${ }^{32}$ as well as monitoring of in situ oxygenation of respiring cells and their responses to metabolic stimulation. ${ }^{33}$

However, for successful application of the probes, in particular, in in vivo experiments, it is highly desirable to use the compounds having specific properties, such as (i) solubility and stability in aqueous media accompanied with internalization into living cells, (ii) emission and excitation shifted as close as possible to the "window of transparency" of biological tissues (650-900 nm), ${ }^{34,35}$ and (iii) appreciable response of emission parameters to the changes in oxygen concentration. The first group of characteristics determines the presence of the probes in living cells and intrinsically implies their amphiphilic nature. Indeed, on the one hand, the probe has to be water (incubation media)-soluble (i.e., to display hydrophilicity) to reach the target from the blood flow; on the other hand, it also has to be hydrophobic to cross phospholipidic cell membranes. Consequently, the design of suitable molecules has to take into account both features, which is a challenging synthetic task.

In general, organometallic complexes are relatively hydrophobic because of the presence in their coordination sphere the ligands based on developed aromatic systems, which are extremely hydrophobic and normally give complete insolubility of these compounds in aqueous media. Thus, it is necessary to incorporate into ligands environment hydrophilic moieties to make the complex molecule amphiphilic. A few approaches can be employed to attain the aim. Encapsulation of luminescent complexes into a cavity of relatively large water-soluble molecules, $^{36}$ covalent, ${ }^{37-41}$ and non-covalent conjugation ${ }^{\mathbf{4 2 - 4 4}}$ with biomolecules substantially increase emitters compatibility with aqueous media to give internalizable luminescent species. In the case of cationic metal complexes a choice of suitable counterions (halides, acetate, etc.) ${ }^{45,46}$ may be helpful in conversion of initially water insoluble entities into readily soluble organometallic emitters. Attachment of hydrophilic substituents (e.g. amino-, amido-carboxy-, imidazo-groups, monosaccharides and peptides $)^{25,33,43,47}$ and water soluble polymeric fragments (polyethylene glycol, ${ }^{24,31,48,49}$ polyvinylpirrolidone, ${ }^{19}$ ) to aromatic chromophores and ancillary ligands makes the luminescent probes soluble in physiological media thus extending the area of their application to in vivo experiments. ${ }^{19,21}$ Another group of ligands, which ensure watersolubility of the corresponding complexes and found a very wide application in homogeneous catalysis, ${ }^{\mathbf{5 0 - 5 2}}$ are sulfonated $N$-heterocyclic carbenes, polypyridines and phosphines. Based on this type of ligands, a rather large variety of water-soluble luminescent $\mathrm{Ru}(\mathrm{II}),{ }^{53} \mathrm{Au}(\mathrm{I}),{ }^{51} \mathrm{Au}(\mathrm{III}),{ }^{54} \mathrm{Pt}(\mathrm{II})^{55}$ and $\operatorname{Ir}(\mathrm{III})^{56}$ complexes were prepared and characterized. However, these complexes were rarely used in bioimaging ${ }^{55}$ and their suitability for advanced imaging experiments needs to be further explored.

In this paper we present systematic synthesis of cyclometalated water-soluble Pt(II) and Ir(III) complexes containing auxiliary sulfonated diphosphine (bis(diphenylphosphino) benzene (dppb), $\left.\mathrm{P}^{\wedge} \mathrm{P}^{*}\right)$ and investigation of their structure and photophysical characteristics, which display considerable variations in emission gap, lifetime and sensitivity to molecular oxygen. The complexes obtained were applied as phosphorescent probes to study their internalization into cancer cells and to image molecular oxygen distribution in in vitro and in vivo tumor models using PLIM technique with one- and two-photon laser excitation.

\section{Experimental section}

\section{General comments}

Cyclometalated precursors $\quad\left[\left(\mathrm{C}^{\wedge} \mathrm{N}\right) \mathrm{Pt}(\mathrm{DMSO}) \mathrm{Cl}\right]^{57}$, $\left[\left(\mathrm{C}^{\wedge} \mathrm{N}\right)_{2} \mathrm{IrCl}_{2}\right]^{58}$, were prepared according to the published procedures. Other reagents were used as received. The solution ${ }^{1} \mathrm{H},{ }^{31} \mathrm{P}\left\{{ }^{1} \mathrm{H}\right\}$ NMR and ${ }^{1} \mathrm{H}_{-}{ }^{1} \mathrm{H}$ COSY spectra were recorded on Bruker Avance 400 and Avance 500 spectrometers with chemical shifts referenced to residual solvent resonances or with respect to $85 \% \mathrm{H}_{3} \mathrm{PO}_{4}, \delta=0 \mathrm{ppm}$. Electrospray ionization (ESI) mass spectra were recorded using a maXis II ESI-QTOF instrument (Bruker, Germany) in the $\mathrm{ESI}^{+}$and $\mathrm{ESI}^{-}$mode. Microanalyses were carried out at the analytical laboratory of the University of Eastern Finland.

\section{Photophysical measurements}

The photophysical measurements in solution were carried out using distilled 1,2-dichloroethane, water was purified with a Simplicity Water Purification System, Merck Millipore (type 1 water). The solutions for lifetime and quantum yield measurements in the absence of oxygen were carefully deoxygenated with three freeze-pump cycles or bubbling solution with argon. UV/Vis spectra were recorded with a Shimadzu UV-1800 spectrophotometer at concentrations of ca. $1 \times 10^{-5} \mathrm{M}(1 \mathrm{~cm}$ cuvettes). Emission and excitation spectra in solution were recorded on a FluoMax-4 (JY Horiba Inc., Japan) spectrofluorimeter using concentration of $c a .4 \times 10^{-5} \mathrm{M}$. The emission quantum yield in solutions was determined by the comparative method $^{59}$ using coumarin 102 in distilled ethanol $\left(\Phi_{\mathrm{r}}=0.764\right)$ as the standard ${ }^{60}$ with the refraction indexes of 1,2-dichloroethane, water, and ethanol equal to 1.44, 1.33, and 1.36, respectively. Lifetimes in solution were determined by the TimeCorrelated Single Photon Counting (TCSPC) method. The lifetime data were fitted using the Jobin-Yvon software package and the Origin 9.0 program. Oxygen-dependent phosphorescence lifetime studies were performed using an Edinburgh (FS920) fluorimeter, Edinburgh FL 900 photon-counting system with a hydrogen-filled lamp as the excitation source (Edinburgh Instruments, UK). Oxygen concentration was adjusted using gas dilution system DS-02 (Peak technology, Taiwan) equipped with 
mass flow controller EL-FLOW Base (Bronkhorst, Netherlands, $1500 \mathrm{sccm}$ ) with nitrogen as the dilution gas. The gas system was connected to thermostatic cuvette holder GS21530 (Specac, UK) with temperature controller Eurotherm 2216e (Specac, UK).

Before phosphorescence decay measurements each sample was bubbled with pre-mixed gas at a defined oxygen concentration for 30 minutes, the temperature of the holder was fixed at $37{ }^{\circ} \mathrm{C}$. The emission decays were fitted using Edinburg Instruments software by nonlinear least square fitting method with the deconvolution of instrument response function.

\section{Complex Pt1}

[ppyPt(DMSO)Cl] (25 mg, $0.054 \mathrm{mmol}$ ) and 1,2-bis(diphenylphosphino)benzene (dppb, $24 \mathrm{mg}, 0.054 \mathrm{mmol}$ ) were dissolved in degassed $\mathrm{CH}_{2} \mathrm{Cl}_{2}(5 \mathrm{~mL})$ (Scheme 1). Then silver trifluoromethanesulfonate (AgOTf, $14 \mathrm{mg}, 0.055 \mathrm{mmol}$ ) was added. The reaction mixture was stirred for $1 \mathrm{~h}$ under a nitrogen atmosphere, and then it was evaporated to dryness. Recrystallization by slow evaporation of a dichloromethane/hexane solution of Pt1 at $+4{ }^{\circ} \mathrm{C}$ gave pale green crystalline material (54 mg, 98\%). ${ }^{1} \mathrm{H}$ NMR (400 MHz, $\mathrm{CD}_{3} \mathrm{OD}, 298 \mathrm{~K}$ ): $\delta 8.42$ (m with broad ${ }^{195} \mathrm{Pt}$ satellites, $\left.1 \mathrm{H}^{1}\right), 8.17\left(\mathrm{~d},{ }^{3} J_{\mathrm{H}-\mathrm{H}}=8.2 \mathrm{~Hz}, 1 \mathrm{H}^{4}\right), 8.06(\mathrm{t}$, $\left.{ }^{3} J_{\mathrm{H}-\mathrm{H}}=7.8 \mathrm{~Hz}, 1 \mathrm{H}^{3}\right), 7.89-7.48\left(\mathrm{~m}, 25 \mathrm{H}^{5,9-13}\right), 7.24-7.15(\mathrm{~m}$, $\left.2 \mathrm{H}^{6,8}\right), 7.02\left(\mathrm{t}, J=6.6 \mathrm{~Hz}, 1 \mathrm{H}^{2}\right), 6.84\left(\mathrm{t},{ }^{3} \mathrm{~J}_{\mathrm{H}-\mathrm{H}}=7.5 \mathrm{~Hz}, 1 \mathrm{H}^{7}\right) \mathrm{ppm}$. ${ }^{31} \mathrm{P}$ NMR $\left(162 \mathrm{MHz}, \mathrm{CD}_{3} \mathrm{OD}, 298 \mathrm{~K}\right): \delta 48.44\left(\mathrm{~d},{ }^{1} J_{\mathrm{P}-\mathrm{Pt}}=1814 \mathrm{~Hz}\right.$, 1P), $36.69\left(\mathrm{~d},{ }^{1} \mathrm{~J}_{\mathrm{P}-\mathrm{Pt}}=3760 \mathrm{~Hz}, 1 \mathrm{P}\right) \mathrm{ppm}$. ES MS $(\mathrm{m} / \mathrm{z}):[\mathrm{M}-$ $\left.\mathrm{CF}_{3} \mathrm{SO}_{3}\right]^{+}$795.174 (calc. 795.166). Anal. calc. for
$\mathrm{C}_{48} \mathrm{H}_{37} \mathrm{~F}_{3} \mathrm{NO}_{3} \mathrm{P}_{2} \mathrm{PtS} \cdot \mathrm{CH}_{2} \mathrm{Cl}_{2}$ (\%): C 53.17; H 3.55; N 1.27; S 2.90. Found: C 53.32; $\mathrm{H} 3.40 ; \mathrm{N} 1.48 ; \mathrm{S} 3.24$.

\section{Complex Pt2}

Prepared analogously to Pt1 using [btpyPt(DMSO)Cl] as starting material (orange crystalline solid, 92\%). ${ }^{1} \mathrm{H}$ NMR $(400 \mathrm{MHz}$, $\left.\mathrm{CD}_{3} \mathrm{OD}, 298 \mathrm{~K}\right): \delta 8.35-8.31\left(\mathrm{~m}, 2 \mathrm{H}^{1,4}\right), 8.28\left(\mathrm{~d},{ }^{3} J_{\mathrm{H}-\mathrm{H}}=8.0 \mathrm{~Hz}, 1 \mathrm{H}^{5}\right)$, $8.11\left(\mathrm{t},{ }^{3} J_{\mathrm{H}-\mathrm{H}}=8.2 \mathrm{~Hz}, 1 \mathrm{H}^{3}\right), 7.86-7.74(\mathrm{~m}, 11 \mathrm{H}), 7.66-7.60(\mathrm{~m}, 6 \mathrm{H})$, $7.59-7.51(\mathrm{~m}, 8 \mathrm{H}), 7.45\left(\mathrm{t},{ }^{3} \mathrm{~J}_{\mathrm{H}-\mathrm{H}}=7.7 \mathrm{~Hz}, 1 \mathrm{H}^{6}\right), 7.28\left(\mathrm{t},{ }^{3} J_{\mathrm{H}-\mathrm{H}}=\right.$ $\left.7.6 \mathrm{~Hz}, 1 \mathrm{H}^{7}\right), 6.95\left(\mathrm{t},{ }^{3} \mathrm{~J}_{\mathrm{H}-\mathrm{H}}=6.6 \mathrm{~Hz}, 1 \mathrm{H}^{2}\right) \mathrm{ppm} .{ }^{31} \mathrm{P} \mathrm{NMR}(162 \mathrm{MHz}$, $\left.\mathrm{CD}_{3} \mathrm{OD}, 298 \mathrm{~K}\right): \delta 48.33\left(\mathrm{~d},{ }^{1} J_{\mathrm{P}-\mathrm{Pt}}=2163 \mathrm{~Hz}, 1 \mathrm{P}\right), 25.09\left(\mathrm{~d},{ }^{1} J_{\mathrm{P}-\mathrm{Pt}}=\right.$ $3462 \mathrm{~Hz}, 1 \mathrm{P})$ ppm. ES MS $(\mathrm{m} / \mathrm{z}):\left[\mathrm{M}-\mathrm{CF}_{3} \mathrm{SO}_{3}\right]^{+} 851.144$ (calc. 851.138). Anal. calc. for $\mathrm{C}_{44} \mathrm{H}_{32} \mathrm{~F}_{3} \mathrm{NO}_{3} \mathrm{P}_{2} \mathrm{PtS}_{2} \cdot \mathrm{CH}_{2} \mathrm{Cl}_{2}$ (\%): $\mathrm{C} 49.78$; H 3.16; N 1.29; S 5.91. Found: C 49.77; H 3.32; N 1.29; S 5.77.

\section{Complex Pt3}

Prepared analogously to Pt1 using [bfpyPtb(DMSO)Cl] as starting material (yellow crystalline solid, 90\%). ${ }^{1} \mathrm{H}$ NMR $(400 \mathrm{MHz}$, $\mathrm{CD}_{3} \mathrm{OD}, 298 \mathrm{~K}$ ): $\delta 8.19\left(\mathrm{~m}\right.$ with broad ${ }^{195} \mathrm{Pt}$ satellites, ${ }^{3} \mathrm{~J}_{\mathrm{Pt}-\mathrm{H}}=$ $\left.28 \mathrm{~Hz}, 1 \mathrm{H}^{1}\right), 8.06\left(\mathrm{td},{ }^{3} J_{\mathrm{H}-\mathrm{H}}=7.8,1.3 \mathrm{~Hz}, 1 \mathrm{H}^{3}\right), 7.99\left(\mathrm{~d},{ }^{3} J_{\mathrm{H}-\mathrm{H}}=\right.$ $\left.7.8 \mathrm{~Hz}, 1 \mathrm{H}^{4}\right), 7.93-7.89\left(\mathrm{~m}, 1 \mathrm{H}^{\mathrm{pp}}\right), 7.86-7.74\left(\mathrm{~m}, 12 \mathrm{H}^{\mathrm{pp}, 5}\right), 7.69-$ $7.58\left(\mathrm{~m}, 8 \mathrm{H}^{\mathrm{PP}}\right), 7.54-7.50\left(\mathrm{~m}, 4 \mathrm{H}^{\mathrm{PP}}\right), 7.29\left(\mathrm{t},{ }^{3} \mathrm{~J}_{\mathrm{H}-\mathrm{H}}=7.5 \mathrm{~Hz}, 1 \mathrm{H}^{6}\right)$, $7.20\left(\mathrm{t},{ }^{3} J_{\mathrm{H}-\mathrm{H}}=7.7 \mathrm{~Hz}, 1 \mathrm{H}^{7}\right), 7.11\left(\mathrm{~d},{ }^{3} J_{\mathrm{H}-\mathrm{H}}=8.2 \mathrm{~Hz}, 1 \mathrm{H}^{8}\right), 6.96$ $\left(\mathrm{m}, 1 \mathrm{H}^{2}\right)$ ppm. ${ }^{31} \mathrm{P}$ NMR (162 MHz, $\left.\mathrm{CD}_{3} \mathrm{OD}, 298 \mathrm{~K}\right): \delta 48.64(\mathrm{~d}$, $\left.{ }^{1} J_{\mathrm{P}-\mathrm{Pt}}=2161 \mathrm{~Hz}, 1 \mathrm{P}\right), 34.02\left(\mathrm{~d},{ }^{1} J_{\mathrm{P}-\mathrm{Pt}}=3498 \mathrm{~Hz}, 1 \mathrm{P}\right) \mathrm{ppm}$. ES MS $(\mathrm{m} / \mathrm{z}):\left[\mathrm{M}-\mathrm{CF}_{3} \mathrm{SO}_{3}\right]^{+} 835.168$ (calc. 835.161). Anal. calc. for
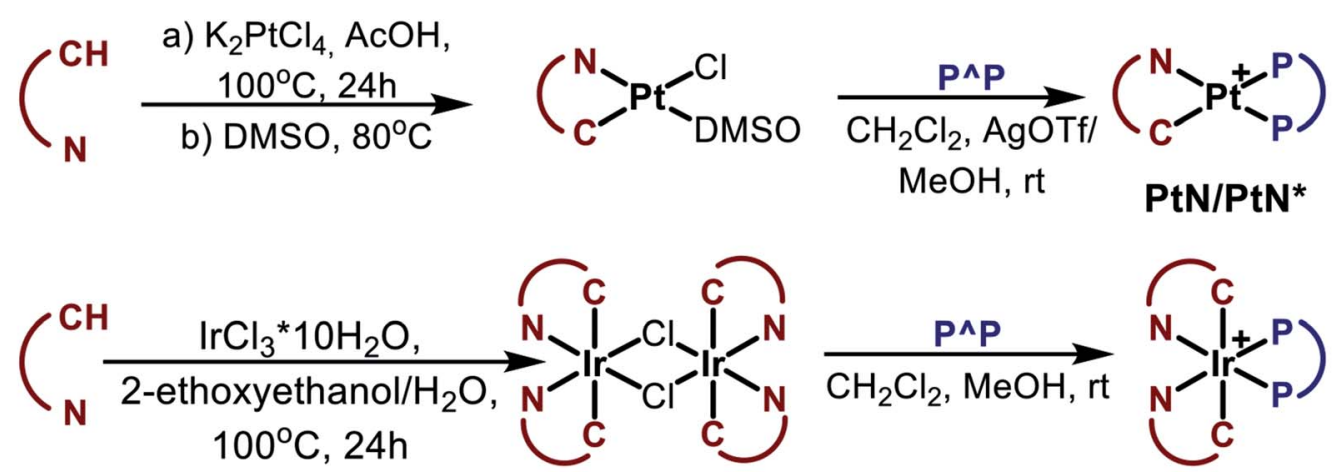

$100^{\circ} \mathrm{C}, 24 \mathrm{~h}$

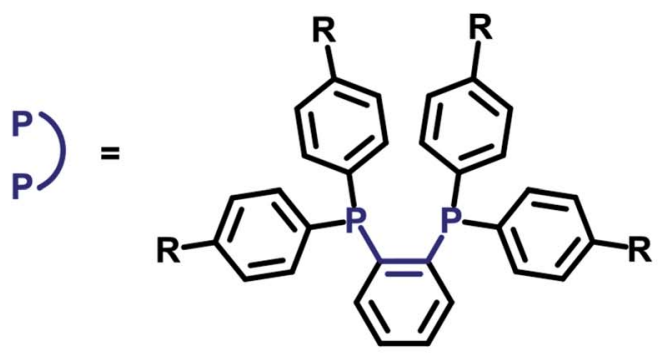

PtN: $\mathbf{R}=\mathbf{H}$
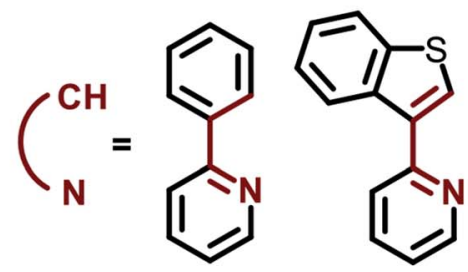

Pt1/Pt1*

Ir1*
IrN*
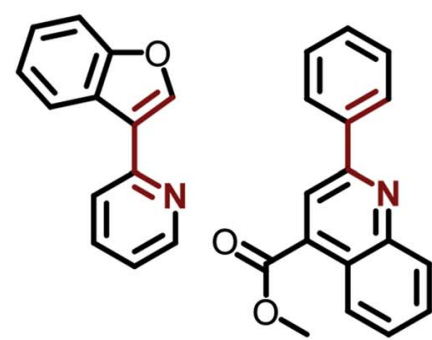

Pt4/Pt4*

Ir2*

Scheme 1 Preparation schemes and chemical structures of the Pt and Ir complexes used in the study. Water-soluble complexes are denoted by asterisks. 
$\mathrm{C}_{44} \mathrm{H}_{32} \mathrm{~F}_{3} \mathrm{NO}_{4} \mathrm{P}_{2} \mathrm{PtS}(\%)$ : C 53.66; H 3.28; N 1.42; $\mathrm{S}$ 3.26. Found: C 53.39; H 3.36; N 1.38; S 3.26.

\section{Complex Pt4}

Prepared analogously to Pt1 using [qpyPt (DMSO)Cl] as starting material (red crystalline solid, 95\%). ${ }^{1} \mathrm{H}$ NMR $(400 \mathrm{MHz}$, $\left.\mathrm{CD}_{3} \mathrm{OD}, 298 \mathrm{~K}\right): \delta 8.44\left(\mathrm{~s}, 1 \mathrm{H}^{5}\right), 8.36\left(\mathrm{~d},{ }^{3} J_{\mathrm{H}-\mathrm{H}}=8.5 \mathrm{~Hz}, 1 \mathrm{H}^{9}\right), 8.29$ $\left(\mathrm{d},{ }^{3} J_{\mathrm{H}-\mathrm{H}}=8.5 \mathrm{~Hz}, 1 \mathrm{H}^{6}\right), 7.84\left(\mathrm{~d},{ }^{3} J_{\mathrm{H}-\mathrm{H}}=7.9 \mathrm{~Hz}, 1 \mathrm{H}^{4}\right), 7.76-7.71$ $\left(\mathrm{m}, 4 \mathrm{H}^{\mathrm{pP}}\right), 7.67\left(\mathrm{~m},{ }^{3} J_{\mathrm{H}-\mathrm{H}}=1.9,7.4 \mathrm{~Hz}, 2 \mathrm{H}^{\mathrm{pP}}\right), 7.61-7.54(\mathrm{~m}$, $\left.7 \mathrm{H}^{\mathrm{pp}}\right), 7.50-7.38\left(\mathrm{~m}, 8 \mathrm{H}^{\mathrm{pp}, 8}\right), 7.25\left(\mathrm{~m},{ }^{3} J_{\mathrm{H}-\mathrm{H}}=13.1,6.6 \mathrm{~Hz}\right.$, $\left.4 \mathrm{H}^{\mathrm{pP}}\right), 7.21-7.11\left(\mathrm{~m}, 2 \mathrm{H}^{1,3}\right), 6.93\left(\mathrm{t},{ }^{3} \mathrm{~J}_{\mathrm{H}-\mathrm{H}}=7.7,1.2 \mathrm{~Hz}, 1 \mathrm{H}^{7}\right)$, $6.78\left(\mathrm{t},{ }^{3} J_{\mathrm{H}-\mathrm{H}}=7.5 \mathrm{~Hz}, 1 \mathrm{H}^{2}\right), 4.11\left(\mathrm{~s}, 3 \mathrm{H}^{6}\right) \mathrm{ppm} .{ }^{31} \mathrm{P} \mathrm{NMR}(162$ $\left.\mathrm{MHz}, \mathrm{CD}_{3} \mathrm{OD}, 298 \mathrm{~K}\right): \delta 42.96\left(\mathrm{~d},{ }^{1} J_{\mathrm{P}-\mathrm{Pt}}=1784 \mathrm{~Hz}\right), 35.95\left(\mathrm{~d},{ }^{1} J_{\mathrm{P}-\mathrm{Pt}}\right.$ $=3872 \mathrm{~Hz}$ ) ppm. ES MS $(\mathrm{m} / \mathrm{z}):\left[\mathrm{M}-\mathrm{CF}_{3} \mathrm{SO}_{3}\right]^{+} 903.194$ (calc. 903.188). Anal. calc. for $\mathrm{C}_{48} \mathrm{H}_{36} \mathrm{~F}_{3} \mathrm{NO}_{5} \mathrm{P}_{2} \mathrm{PtS}(\%)$ : $\mathrm{C} 54.76 ; \mathrm{H}$ 3.45; N 1.33; S 3.05. Found: C 54.67; H 3.39; N 1.31; S 3.31.

\section{Complex Ir1*}

Complex was obtained as compound Pt1*. Yield 85\%, pale green amorphous solid. ${ }^{1} \mathrm{H}$ NMR (400 MHz, $\mathrm{CD}_{3} \mathrm{OD}, 298 \mathrm{~K}$ ): o $8.21\left(\mathrm{~m}, 1 \mathrm{H}^{9}\right), 8.09-8.03\left(\mathrm{~m}, 1 \mathrm{H}^{10}\right), 7.87\left(\mathrm{~m}, 2 \mathrm{H}^{11}\right), 7.73(\mathrm{~m}$, $\left.2 \mathrm{H}^{12}\right), 7.66\left(\mathrm{~d},{ }^{3} J_{\mathrm{H}-\mathrm{H}}=7.7 \mathrm{~Hz}, 1 \mathrm{H}^{4}\right), 7.61\left(\mathrm{~d},{ }^{3} J_{\mathrm{H}-\mathrm{H}}=7.9 \mathrm{~Hz}, 1 \mathrm{H}^{5}\right)$, $7.56\left(\mathrm{t},{ }^{3} J_{\mathrm{H}-\mathrm{H}}=7.5 \mathrm{~Hz}, 1 \mathrm{H}^{3}\right), 7.33\left(\mathrm{~d},{ }^{3} J_{\mathrm{H}-\mathrm{H}}=5.8 \mathrm{~Hz}, 1 \mathrm{H}^{1}\right), 7.20$ $\left(\mathrm{m}, 2 \mathrm{H}^{11}\right), 7.03\left(\mathrm{t},{ }^{3} J_{\mathrm{H}-\mathrm{H}}=7.4 \mathrm{~Hz}, 1 \mathrm{H}^{6}\right), 6.92\left(\mathrm{t},{ }^{3} J_{\mathrm{H}-\mathrm{H}}=7.4 \mathrm{~Hz}\right.$, $\left.1 \mathrm{H}^{7}\right), 6.45-6.39\left(\mathrm{~m}, 3 \mathrm{H}^{12,2}\right), 6.16\left(\mathrm{dd},{ }^{3} J_{\mathrm{H}-\mathrm{H}}=7.4,3.2 \mathrm{~Hz}\right.$, $1 \mathrm{H}^{8}$ ) ppm. ${ }^{31} \mathrm{P}$ NMR (162 MHz, $\mathrm{CD}_{3} \mathrm{OD}, 298 \mathrm{~K}$ ): $\delta 21.76$ (s) ppm. ES MS $(m / z):[\mathrm{M}-3 \mathrm{Na}]^{3-} 421.026$ (calc. 421.009$),[\mathrm{M}-3 \mathrm{Na}+$ $\mathrm{H}]^{2-} 632.042$ (calc. 632.017), $[\mathrm{M}-2 \mathrm{Na}]^{2-} 643.035$ (calc. 643.008), [2M - 3Na $]^{3-} 865.041$ (calc. 865.007).

\section{Complex Ir2*}

Complex was obtained analogous to compound Pt2*. The synthesis procedures of Pt1*-Pt4* complexes are given in ESI. $\dagger$ Yield $65 \%$, orange amorphous solid. ${ }^{1} \mathrm{H}$ NMR $(400 \mathrm{MHz}$, $\left.\mathrm{CD}_{3} \mathrm{OD}, 298 \mathrm{~K}\right): \delta 8.58\left(\mathrm{~m}, 1 \mathrm{H}^{10}\right), 8.42\left(\mathrm{~s}, 1 \mathrm{H}^{5}\right), 8.36\left(\mathrm{dd},{ }^{3} J_{\mathrm{H}-\mathrm{H}}=\right.$ $\left.8.5,{ }^{4} J_{\mathrm{H}-\mathrm{H}}=1.2 \mathrm{~Hz}, 1 \mathrm{H}^{4}\right), 8.18\left(\mathrm{~m}, 1 \mathrm{H}^{11}\right), 7.99\left(\mathrm{~d},{ }^{3} J_{\mathrm{H}-\mathrm{H}}=8.1 \mathrm{~Hz}\right.$, $\left.1 \mathrm{H}^{6}\right), 7.60\left(\mathrm{~m}, 4 \mathrm{H}^{12,13}\right), 7.53\left(\mathrm{dd},{ }^{3} J_{\mathrm{H}-\mathrm{H}}=8.8,{ }^{4} J_{\mathrm{H}-\mathrm{H}}=3.5 \mathrm{~Hz}\right.$, $\left.1 \mathrm{H}^{1}\right), 7.27\left(\mathrm{t},{ }^{3} J_{\mathrm{H}-\mathrm{H}}=8.1 \mathrm{~Hz}, 1 \mathrm{H}^{3}\right), 7.17\left(\mathrm{t},{ }^{3} J_{\mathrm{H}-\mathrm{H}}=7.5 \mathrm{~Hz}, 1 \mathrm{H}^{7}\right)$, $6.88\left(\mathrm{t},{ }^{3} J_{\mathrm{H}-\mathrm{H}}=7.5 \mathrm{~Hz}, 1 \mathrm{H}^{8}\right), 6.76\left(\mathrm{~m}, 2 \mathrm{H}^{12}\right), 6.41\left(\mathrm{t},{ }^{3} J_{\mathrm{H}-\mathrm{H}}=\right.$ $\left.8.5 \mathrm{~Hz}, 1 \mathrm{H}^{2}\right), 6.32\left(\mathrm{~m}, 2 \mathrm{H}^{13}\right), 5.88\left(\mathrm{dd},{ }^{3} J_{\mathrm{H}-\mathrm{H}}=7.7,{ }^{4} J_{\mathrm{H}-\mathrm{H}}=\right.$ $\left.3.5 \mathrm{~Hz}, 1 \mathrm{H}^{9}\right), 4.04\left(\mathrm{~s}, 3 \mathrm{H}^{14}\right) \mathrm{ppm} .{ }^{31} \mathrm{P} \mathrm{NMR}\left(162 \mathrm{MHz}, \mathrm{CD}_{3} \mathrm{OD}\right.$, $298 \mathrm{~K}): \delta 13.53(\mathrm{~s}) \mathrm{ppm}$. ES MS $(\mathrm{m} / \mathrm{z}):[\mathrm{M}-3 \mathrm{Na}]^{3-} 493.023$ (calc. 493.023), $[\mathrm{M}-2 \mathrm{Na}]^{2-} 751.031$ (calc. 751.029), $[2 \mathrm{M}-3 \mathrm{Na}]^{3-}$ 1009.036 (calc. 1009.036).

\section{$\mathrm{X}$-ray structure determination}

The crystals of Pt1, Pt2 and Pt4 were immersed in cryo-oil, mounted in a Nylon loop, and measured at a temperature of $150 \mathrm{~K}$. The X-ray diffraction data were collected with Bruker SMART APEX II and Bruker Kappa Apex II Duo diffractometers using Mo $\mathrm{K} \alpha$ radiation $(\lambda=0.71073 \AA)$. The APEX2 program package $^{61}$ was used for cell refinements and data reductions. The structures were solved by direct methods using the SHELXS-2014 (ref. 62) program with the WinGX ${ }^{63}$ graphical user interface. A semiempirical absorption correction (SADABS) ${ }^{\mathbf{4}}$ was applied to all data. Structural refinements were carried out using SHELXL-2014. ${ }^{62}$ One phenyl ring of the diphosphine ligand in Pt1 and triflate counterion were disordered between two orientations each and were refined with occupancies of $0.63 / 0.37$ and $0.69 / 031$, respectively; geometry and displacement restraints and constraints were applied to these moieties. The crystallization solvent in Pt2 was partially lost from the crystal and could not be resolved unambiguously. The contribution of the missing solvent to the calculated structure factors was taken into account by using a SQUEEZE routine of PLATON. ${ }^{65}$ The missing solvent was not taken into account in the unit cell content. The structure of 6 was refined as a 2-component inversion twin. All $\mathrm{H}$ atoms in 1-6 and 8-11 were positioned geometrically and constrained to ride on their parent atoms, with $\mathrm{C}-\mathrm{H}=0.95-0.99 \AA$ and $U_{\text {iso }}=1.2-1.5 U_{\text {eq }}$ (parent atom). The crystallographic details are summarized in Table S1. $\dagger$

\section{Two-photon image experiments in vitro}

For cell imaging experiments, about $5 \times 10^{4}$ HeLa cells were seeded in a $35 \mathrm{~mm}$ glass-bottom dish well with $2 \mathrm{~mL}$ of DMEM included. Incubation condition is at $37^{\circ} \mathrm{C}$ and $\mathrm{CO}_{2}$ to air ratio of 5 : 95. After $24 \mathrm{~h}$ of incubation, each dish was washed three times with PBS buffer solution and then introduced with $50 \mu \mathrm{M}$ of iridium complex (for Ir1* and Ir2*) or $75 \mu \mathrm{M}$ of platinum complex (for Pt2*, Pt3*, Pt4*). After this 18 hours incubation of metal complex, HeLa cells were washed three times with PBS buffer solution and then added phenol red-free culture medium in each dish. Finally, HeLa cells were studied by a Zeiss LSM710 confocal laser-scanning microscope with $63 \times$ objective for observation (P-APO, 1.40 oil immersion). The $80 \mathrm{MHz}, 100 \mathrm{fs}$ mode-locked Ti:sapphire laser (Mai-Tai DeepSee, SpectraPhysics) was used as a two-photon excitation light source. The temperature was maintained at $37^{\circ} \mathrm{C}$ during the experiments.

\section{Phosphorescence lifetime imaging (PLIM) in vitro}

Zeiss LSM 710 (Zeiss, Germany) equipped with $80 \mathrm{MHz}$ fs modelocked Ti:sapphire laser (Mai-Tai DeepSee, Spectra-Physics) was used for the experiments. All data were collected using PlanApochromat $63 \times / 1.4$ oil immersion objective lens (Zeiss, Germany). To make time-resolved luminescence imaging we used time-correlated single-photon counting board SPC-150, 16channel spectral detector PML-16-1-C and programmable pulse generator DDG-210 (Becker\&Hickl GmbH, Germany). The DDG210 is triggered by the pixel clock of the LSM 710 and delivers a laser modulation signal of programmable width, which is fed back into the beam blanking system of the microscope. The modulation of the laser signal on the pixel dwell time allows to record fluorescence and phosphorescence lifetime images simultaneously. ${ }^{66}$ Basically, when the laser is on the fluorescence signal is recorded and phosphorescence emission is built up, and when it is switched off, only phosphorescence signal is collected. The detailed operation of the FLIM/PLIM with Zeiss LSM systems can be found elsewhere. ${ }^{67}$ The TCSPC data were analyzed by the SPCImage 6.0 software (Becker \& Hickl GmbH, Germany). 


\section{In vitro cytotoxicity - MTT assay}

For determining the cytotoxicity of metal complexes to HeLa cell, MTT assay was conducted by using a common colorimetric assay agent, 3-(4,5-dimethylthiazol-2-yl)-2,5-diphenyltetrazolium bromide (MTT, Roche, Germany). At first, HeLa cells were seeded in a 96-well incubation plate with $5 \times 10^{3}$ cells per well in a 90\% Dulbecco's Modified Eagle Medium (HyClone, GE Healthcare, USA) along with $10 \%$ heat-inactivated fetal bovine serum (HyClone, GE Healthcare, USA). To compare the cytotoxicity effect of different metal complex concentration, six different concentrations were prepared for each plate $(0-70 \mu \mathrm{M}$ for Ir1*, Ir2*; 0-150 $\mu \mathrm{M}$ for Pt2*, Pt3*, and Pt4*). After 24 hours of incubation, every well was washed twice with PBS buffer solution, followed by addition of $200 \mu \mathrm{L}$ of the culture medium containing $10 \%$ MTT agent. After 3 hours of reaction time, the culture medium was removed and $200 \mu \mathrm{L}$ of dimethyl-sulfoxide (Merck, USA) was added to dissolve the deposited purple formazan crystal in the cell. The absorbance of the complexes was recorded at $595 \mathrm{~nm}$. All experimental results (average and standard deviation) were calculated from three replicates collected by an ELISA reader system (VersaMax $^{\mathrm{TM}}$ Microplate Spectrophotometers; Molecular-Devices, USA).

\section{Photostability experiments}

Photostability study of the metal complexes was compared with commonly used chromophores (coumarin 480 and rhodamine B), which possess similar absorption and emission bands. Samples were dissolved in PBS $(10 \mathrm{mM}, \mathrm{pH}=7.4)$. Absorbances are all fixed to 0.05 at $360 \mathrm{~nm}$ (For Ir1* and C480, $\lambda_{\text {exc }}=720 \mathrm{~nm}$ ) or at $430 \mathrm{~nm}$ (For Ir2 $*$, Pt2 ${ }^{*}, \mathbf{P t} 3 *$, Pt4 $*$ and rhodamine $\mathrm{B}, \lambda_{\mathrm{exc}}=$ $860 \mathrm{~nm}$ ). The excitation power was $32 \mathrm{~mW}$ at the objective lens. Luminescence intensity at the emission maxima was recorded with continuous exposure to excitation with 50 scan times with time interval of 2.0 seconds. Data was collected by Zeiss LSM710 microscope equipped with $63 \times$ objective $(\mathrm{P}-\mathrm{APO}, \mathrm{NA}=1.40$, oil immersion).

\section{Tumor model}

Experiments were performed on female athymic nude mice purchased from the Pushchino animal nursery (Pushchino, Russia). To generate tumors, mice of 20-22 $\mathrm{g}$ body weight were injected subcutaneously in the left flank with HeLa cells $(2 \times$ $10^{6}$ in $200 \mu \mathrm{L}$ PBS). Experiments were carried out in 14 days after the cell injection, when the tumors reached $\sim 10-12 \mathrm{~mm}$ in size. For imaging procedures the mice were anesthetized intramuscularly with a mixture of Zoletil (40 $\mathrm{mg} \mathrm{kg}^{-1}, 50 \mu \mathrm{L}$, Virbac SA, Carros, France) and $2 \%$ Rometar $\left(10 \mathrm{mg} \mathrm{kg}^{-1}, 10 \mu \mathrm{L}\right.$, Spofa, Czech Republic), and a skin flap over the tumor was surgically opened. After image acquisition, the animals were sacrificed by cervical dislocation and the tumors were excised for histopathology. For animal study, Ir1* was dissolved in distilled water in a concentration $30 \mathrm{mg} \mathrm{mL} \mathrm{m}^{-1}$ and injected topically, directly into the tumor or muscle $20-30 \mathrm{~min}$ prior to the study $(50 \mu \mathrm{L}$ of solution in 4-6 injections, total dose $75 \mathrm{mg} \mathrm{kg}^{-1}$ body weight).
Tumor-bearing mice that did not receive the injection of $\operatorname{Ir} 1^{*}$ served as control.

\section{Two-photon microscopy in vivo}

An LSM 880 (Carl Zeiss, Germany) fluorescence confocal laserscanning microscope equipped with a femtosecond Ti:Sapphire laser with a repetition rate of $80 \mathrm{MHz}$ and pulse duration of 140 fs was used to obtain two-photon fluorescence images. The images were acquired through a water immersion objective C-Apochromat $40 \times / 1.2 \mathrm{NA} \mathrm{W}$ Korr. For in vivo image acquisition, an anesthetized animal was placed on the glass cover slip, so that the objective was focused on the region of interest (tumor or muscle surface). Ir $\mathbf{1}^{*}$ was excited at a wavelength of $750 \mathrm{~nm}$, emission was detected in the range 430-600 nm. For spectral imaging, emitted light was collected in the spectral range of 400-662 $\mathrm{nm}$ under lambda mode.

\section{PLIM in vivo}

A confocal scanning system for macroscopic objects DCS-120 MACRO (Becker \& Hickl GmbH, Germany) equipped with a TCSPC-based module was used for one-photon PLIM of tumors in vivo. Ir1* was excited with a picosecond diode laser at 405 nm (BDL-SMN-405, Becker\&Hickl GmbH, Germany). Long pass (HQ435LP, Chroma, USA) and dichroic $560 \mathrm{~nm}$ (Chroma, USA) filters have been used to suppress the emission from the laser. The PLIM data were processed using SPCImage software (Becker \& Hickl GmbH, Germany). Phosphorescence lifetime analysis was performed for 5 tumor nodules and 3 areas of muscles in 2 mice by selecting specific regions of interest. Data were represented as mean $\pm \mathrm{SD}$.

This study was performed in strict accordance with the Russian national guidelines for the use of laboratory animals (the USSR Ministry of Higher and Middle Professional Education, Decreet No. 742, dated 13.11.1984) and was approved by the Ethical Committee of the Privolzhsky Research Medical University (Nizhny Novgorod, Russia).

\section{Results and discussion}

\section{Synthesis and photophysical study of Pt(II) and Ir(II) complexes}

Cyclometalated platinum(II) and iridium (III) complexes containing hydrophobic and water soluble diphosphines were obtained in good yield using slightly modified conventional procedures (Scheme 1). The complexes based on sulfonated 1,2bis(diphenylphosphino)benzene (dppb) display excellent solubility and stability in aqueous media, good cellular uptake and very low cytotoxicity that provide a background for their application in imaging experiments (vide infra). For details of synthetic procedures and structural characterization (XRD, mass-spectrometry, NMR spectroscopy) of the platinum and iridium compounds see ESI, Section $1 . \dagger$

All complexes obtained excluding platinum phenylpyridine derivatives Pt1 and Pt1* are luminescent in organic solvents (Pt2-Pt4) and in aqueous solution (Pt2*-Pt4* and Ir1*, Ir2*). Their photophysical characteristics are summarized in Table 1; 
excitation and emission spectra are shown in Fig. 1. Absorption spectra and additional discussion of the spectroscopic properties are given in ESI file (Section 2). $\dagger$

It can be easily seen that emission profiles of the hydrophobic and water-soluble platinum congeners (PtN-PtN*) are essentially similar, which is indicative of negligible effect of the phosphine ligands onto emission characteristics. The platinum complexes display a rather weak luminescence in fluid media with the broaden emission bands containing ill-defined vibronic structure that is in agreement with the predominant MLCT nature of emissive excited state associated mainly with metalating ligands. Large stokes shifts and lifetimes in the microsecond domain clearly show that emission occurs from the lowest triplet manifold, i.e. phosphorescence. Expansion of aromatic system in the $\mathrm{C}^{\wedge} \mathrm{N}$ ligand and introduction of electron accepting substituent into quinoline fragment in the $\mathbf{P t 4} / \mathbf{P t} \mathbf{4}^{*}$ complexes results in a considerable bathochromic shift of the emission maxima in accord with the well-known trend revealed for metalated platinum complexes. ${ }^{68}$ It has to be noted that the effect of emission quenching with molecular oxygen is very minor for these platinum complexes, which makes difficult their application as oxygen sensors, with the only exclusion of Pt2* where quantum yields in degassed aqueous solution is four times higher than that in the aerated solution.

The photophysics of the $\left[\operatorname{Ir}\left(\mathrm{C}^{\wedge} \mathrm{N}\right)_{2}\left(\mathrm{X}^{\wedge} \mathrm{X}\right)\right]^{1+/ 0}$ iridium complexes $(\mathrm{X}=\mathrm{N}, \mathrm{P}, \mathrm{O})$ have been extensively studied during the last decade ${ }^{69}$ because of attractive luminescent characteristics of these molecular emitters, in particular, for application in bioimaging. ${ }^{2,10}$ It has to be mentioned that a complete analogue of Ir1* with non-sulfonated diphosphine (Ir1) was earlier prepared and studied experimentally and theoretically. ${ }^{70,71}$ Similar to the platinum relatives, the peak wavelengths and profiles of the absorption and emission bands for Ir ${ }^{*}$ and its Ir1 analogue ${ }^{70,71}$ are nearly identical. The result points to similarity of their electronic structure and likeness of the nature of emissive transitions. Consequently, the emission of the Ir1 and Ir $1 *$ compounds may be assigned to a combination of metal perturbed IL and MLCT excited states with substantial contribution of the former that is also indicated by vibronically structured emission band. Ir2* containing substituted quinoline fragment in the metalating ligand displays a substantial red shift of emission and transformation of the emission profile into structureless band that points to domination of MLCT process in generation of the emissive excited state in this complex. Sensitivity of emission parameters to molecular oxygen for Ir ${ }^{*}$ and Ir2* is rather different; the higher degree of emission quenching with $\mathrm{O}_{2}$ has been found for Ir1*, which may be related to lower shielding of the chromophoric center in the phenyl pyridine complex and provides a background for the complex application in phosphorescence lifetime imaging (PLIM) experiments aimed at oxygen mapping in biological samples (vide infra).

To further evaluate applicability of the water-soluble iridium complexes for the bioimaging applications, we measured their two-photon absorption (TPA) cross sections $\left(\sigma_{2}\right)$ in water via a Zscan method (see Experimental section in ESI, and Fig. S36†). Using a femtosecond laser ( $\left.\lambda_{\mathrm{em}} 800 \mathrm{~nm}, 180 \mathrm{fs}, 1 \mathrm{kHz}\right), \sigma_{2}$ values of Ir1* and Ir2* in water were measured to be $627 \pm 9$ GM and $655 \pm 46 \mathrm{GM}$, correspondingly ( $1 \mathrm{GM}=10^{-50} \mathrm{~cm}^{4} \mathrm{~s}$ per photon).

These values are comparable to the highest TPA cross section values among the iridium complexes reported in the literature. ${ }^{72-75}$ As for the titled platinum complexes, the same excitation wavelength $(800 \mathrm{~nm})$ is applied at Pt2*, Pt3* and Pt4* in water, and their TPA cross sections were measured to be $416 \pm 29 \mathrm{GM}, 400 \pm$

Table 1 Photophysical properties of complexes

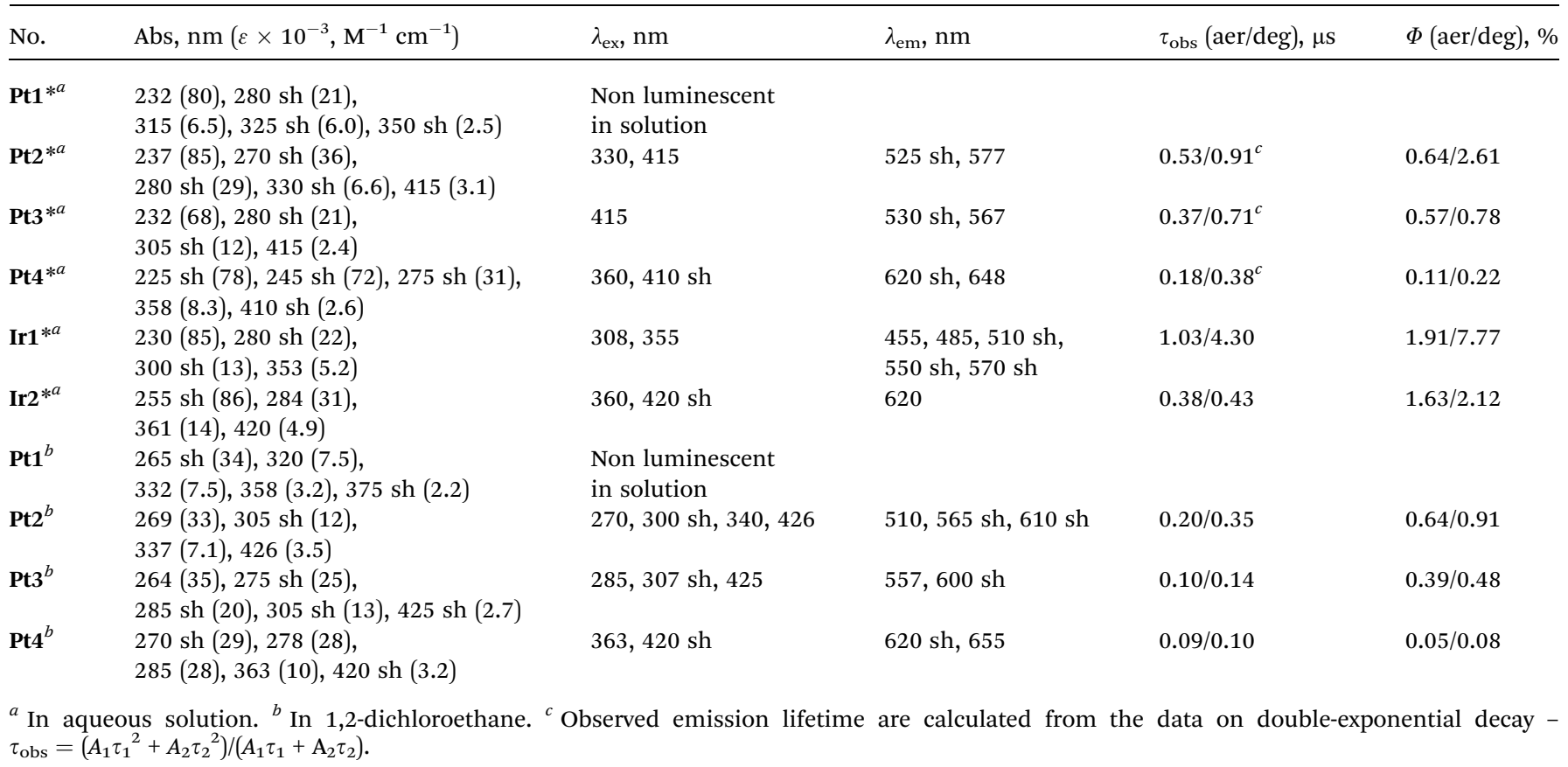



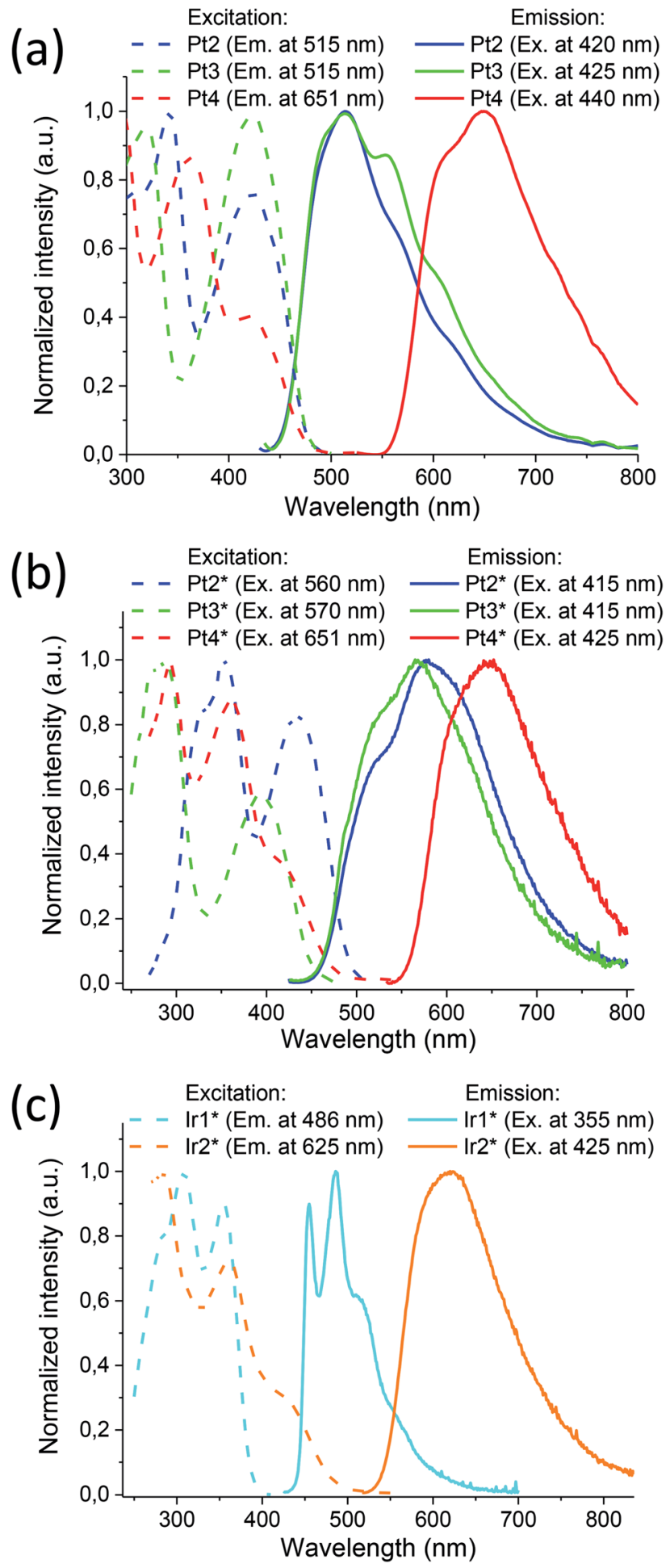

Fig. 1 Normalized excitation (dashed) and emission (solid) spectra: (a) Pt2, Pt3 and Pt4 in 1,2-dichloroethane $\left(\lambda_{\text {ex }}=420 \mathrm{~nm}\right.$ for Pt2, $425 \mathrm{~nm}$ for Pt3, $440 \mathrm{~nm}$ for Pt4), (b) Pt2*, Pt3* and Pt4* in aqueous solution $\left(\lambda_{\text {ex }}=415 \mathrm{~nm}\right.$ for Pt2* and Pt3*, $425 \mathrm{~nm}$ for Pt4*), (c) Ir1* and Ir2* in aqueous solution, $\left(\lambda_{\mathrm{ex}}=355\right.$ and $425 \mathrm{~nm}$ for Ir1* and Ir2*, respectively).

$50 \mathrm{GM}$, and $496 \pm 44 \mathrm{GM}$, respectively, which are also comparable with that of potential Pt complexes for two-photon imaging. ${ }^{55,76-80}$
Analyses of the whole set of the photophysical data including measurements of TPA cross-sections show that Ir1* is the most suitable species for oxygen concentration mapping using PLIM technique since it shows the largest dynamic range of lifetimes (more than 4 -fold increase in degassed state) and the highest $\Phi_{\text {deg }}$ and $\sigma_{2}$ values. To evaluate applicability of this complex for PLIM measurements we carried out a series of test experiments in solution, in vitro and in vivo: quantification of the lifetime characteristics on the oxygen concentration in solution, cytotoxicity assay and two photon imaging in PLIM mode on HeLa cells, as well as in vivo PLIM of nude mice bearing HeLa tumors.

\section{Phosphorescence quenching}

We performed exploration of Ir1* response to variations in oxygen concentration in attempts to monitor the cell hypoxia effect due to its potential correlation with tumor proliferation. ${ }^{26}$ In some cases, for example, the intracellular oxygen concentration in solid tumors can drop down to almost $\sim 0 \% .^{26,27,81}$

There have been a number of oxygen-sensitive luminescent materials designed for monitoring intracellular oxygen level and tumor hypoxia, ${ }^{\mathbf{1 1 , 2 1 , 8 2 - 8 5}}$ among which the phosphors based on transition-metal complexes have attracted considerable attention for their promising applications in imaging. The dynamic quenching of phosphorescence due to collisional energy transfer to the triplet ground state $\mathrm{O}_{2}$ molecules results in the radiationless deactivation of the phosphor lowest triplet state and lets phosphorescent emitters become suitable $\mathrm{O}_{2}$ sensors. Practically, $\mathrm{O}_{2}$ sensors based on this phenomenon increase their emission intensity and lifetime as the oxygen concentration decreases thus making detection of tumor hypoxia possible.

The ratio of phosphorescence lifetime is related to the concentration of existing quencher, i.e., oxygen, according to the well-known Stern-Volmer eqn (1),

$$
\frac{I_{0}}{I}=\frac{\tau_{0}}{\tau}=1+K_{\mathrm{SV}}[\mathrm{Q}]
$$

where $I$ and $\tau$ are the phosphorescence emission intensity and lifetime at a certain quencher concentration [Q], $I_{0}$ and $\tau_{0}$ correspond to zero quencher concentration, and $K_{\mathrm{SV}}$ is the Stern-Volmer constant. Fig. 2a shows the phosphorescence decay of Ir1* under various oxygen pressures at $37{ }^{\circ} \mathrm{C}$. The resulting Stern-Volmer plot shown in Fig. 2 b renders a $K_{\mathrm{SV}}$ value of $5.54 \mathrm{~atm}^{-1}$. This, together with its good emission yield and excellent stability in the course of the PLIM experiments (3-5 minutes, vide infra), meets the requirement of hypoxia effect monitoring by PLIM. ${ }^{82}$

\section{Cellular uptake and cytotoxicity of Ir $1 *$ on HeLa cells}

We applied laser-scanning microscopy (LSM) combined with two-photon excitation technique to study cellular uptake of water-soluble complexes developed in the present study. The two-photon excitation microscopy offers larger penetration depth and lower photodamage for intact tissue image in comparison with one-photon excitation. ${ }^{31,86}$ The LSM 

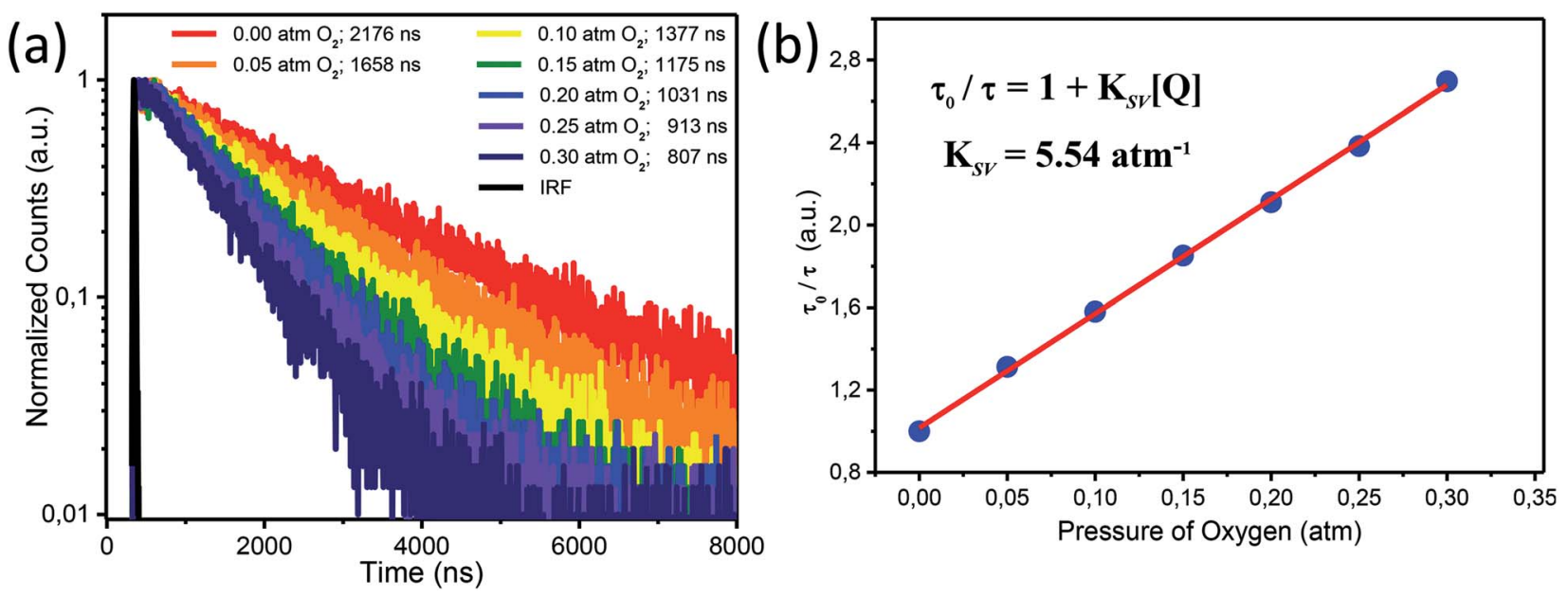

Fig. 2 (a) Phosphorescence decay curves (corresponding lifetimes are listed in the legend) of Ir1* in water under different oxygen pressures at $37^{\circ} \mathrm{C}$. (b) The resulting Stern-Volmer plot of Ir1* quenching by oxygen.

experiments indicated successful uptake of Ir1* by HeLa cells (18 hours incubation), and its primarily location within the cytoplasm (Fig. S37†). Note that similar behavior was observed for other water-soluble complexes (Fig. S38†) indicating that negatively charged complexes bearing sulfo groups can penetrate cells despite of electrostatic repulsion at cell membrane. This behavior can be attributed to amphiphilic nature of these complexes bearing not only hydrophilic phopshine ligands but also hydrophobic groups facilitating crossing cell membranes.

Since cell-permeable transition metal complexes can potentially be highly cytotoxic, we have also performed MTT assay test to evaluate their cytotoxicity. The results (Fig. S39†) show that, upon incubation of HeLa cells with Ir1* and Ir2* up to $70 \mu \mathrm{M}$ for 24 hours, more than $95 \%$ of HeLa cells has survived regardless of the complexes concentrations, affirming low cytotoxicity for both Ir1* and Ir2*. Analogously, the Pt complexes revealed no cytotoxic effect up to $70 \mu \mathrm{M}$ for 24 hours, and rather high $\mathrm{IC}_{50}$ values ranging from 110 to $140 \mu \mathrm{M}$ (Fig. S40†).

\section{Two-photon in vitro PLIM on HeLa cells}

For $\mathrm{O}_{2}$ sensing, the detection modalities can be categorized by emission intensity and lifetime measurements. The emission intensity assay can be attained either by monitoring at a single wavelength of $\mathrm{O}_{2}$-sensitive dye or by the ratiometric intensity referred to a $\mathrm{O}_{2}$-insensitive moiety. ${ }^{7}$ Unfortunately, this modality commonly encounters interferences from autofluorescence and dye delivery dynamics to the cell, which makes it difficult to quantify oxygen content. ${ }^{11}$ Compared with nanosecond-scale autofluorescence, fortunately, the phosphorescence originating from transition metal complexes possesses much longer (microsecond) lifetimes, so that the time-gated method is a superior technique benefitting from the above difference in the time scale. ${ }^{11}$ Accordingly, the phosphorescence lifetime imaging (PLIM) becomes a powerful tool in investigating lifetime distribution of phosphorescent materials in cell or tissue and hence in tracking of oxygen concentrations. ${ }^{12}$ Fig. 3 shows two-photon absorption PLIM of HeLa cells incubated with $50 \mu \mathrm{M}$ Ir1* under standard oxygenated environment (Fig. 3a-c) and under $\mathrm{N}_{2}$ saturated atmosphere (Fig. 3d-f). In these images (panels b and e) the phosphorescence lifetime is symbolized by colors from blue (short decay) to red (long decay). The data obtained (Fig. 3c and f) indicate that the lifetime distribution of Ir1* in HeLa cells under the $\mathrm{N}_{2}$ saturated atmosphere is significantly longer than that in the standard atmosphere. The amplitude weighted mean lifetime was calculated to be 1.05 and $2.17 \mu$ s for standard and $\mathrm{N}_{2}$ saturated atmosphere, respectively (with relative uncertainty in lifetime calculations not exceeding 5\%), affirming the potential of Ir1* for detecting intracellular oxygen level and hence monitoring hypoxia in vitro.

The photostability of phosphorescence probes plays a key role in PLIM measurements. Under the high photon flux used in two photon excitation, photobleaching may take place during the data acquisition. This may cause a serious problem for PLIM since it requires a few minutes to collect sufficient data for lifetime analyses. For a fair photostability evaluation, we compared iridium complexes Ir ${ }^{*}$ and Ir ${ }^{*}$ with common luminophores coumarin 480 (C480) and rhodamine B.

Under the same power and excitation wavelength $\left(\lambda_{\mathrm{exc}}=\right.$ $720 \mathrm{~nm}$ for Ir1* and C480, and $\lambda_{\mathrm{exc}}=860 \mathrm{~nm}$ for Ir2*, Pt2*, Pt3*, Pt4* and rhodamine B), together with 50 scans (acquisition time of every scan is 1.94 second), each scan interval of 2 seconds, the emission intensity of C480 and rhodamine B dropped rapidly, whereas the emission intensity of Ir1* and Ir2* still exceeded $97 \%$ of the first scan emission intensity (see Fig. 4). In the similar way, photostabilities of Pt complexes were found to be higher than that of rhodamine B, though slightly lower than those of Ir complexes (Fig. S41†). We thus concluded that the titled water-soluble iridium complexes, especially Ir1*, are robust and have great photostability suitable for the PLIM measurements in vitro. In the next section, we have then evaluated its applicability for PLIM experiments in vivo.

\section{Evaluation of Ir1* applicability for in vivo PLIM imaging}

In order to demonstrate the applicability of Ir1* to oxygen measurements in animal tissues, we performed in vivo experiments on mice with HeLa tumor xenografts. 

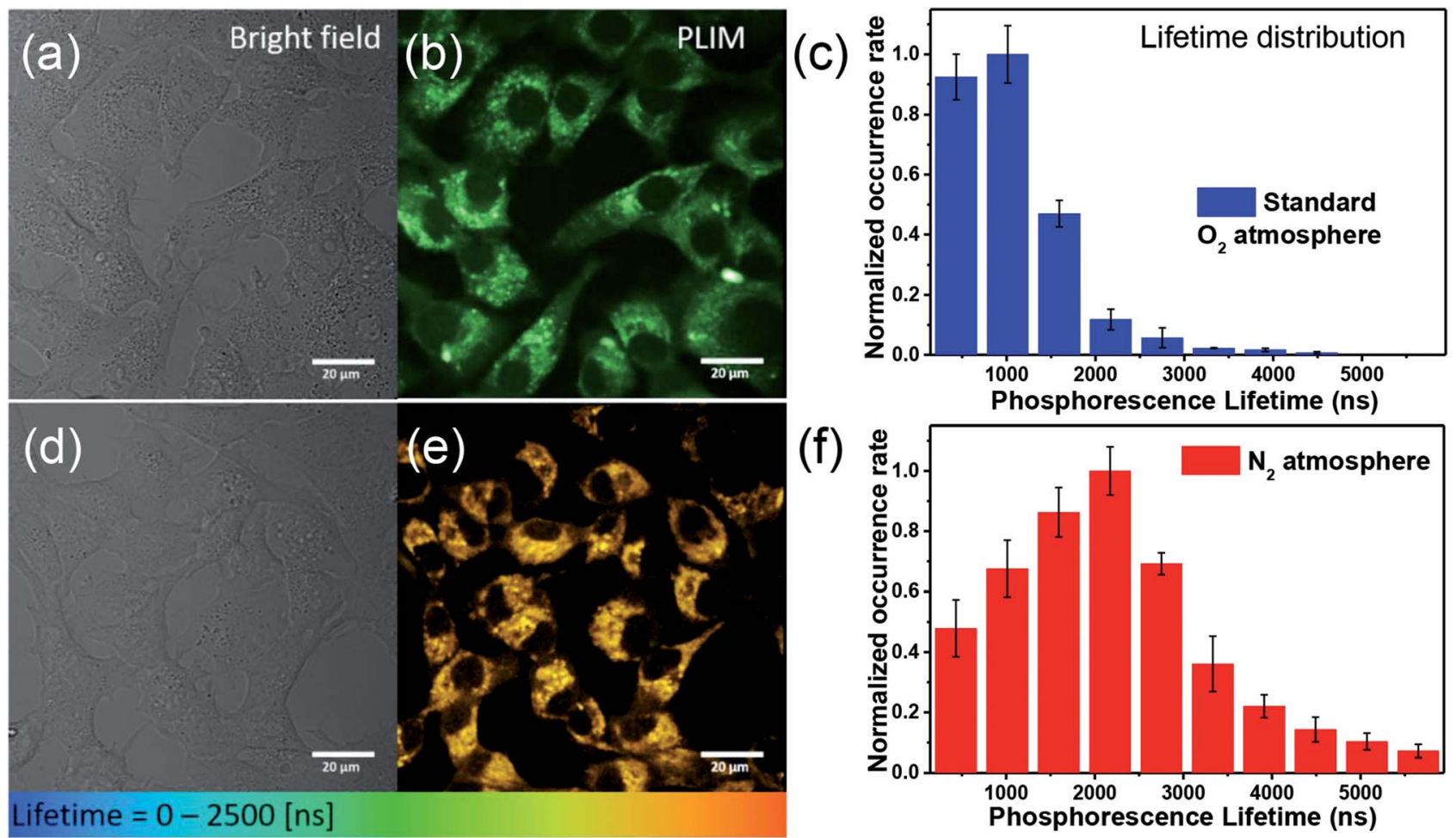

(f)

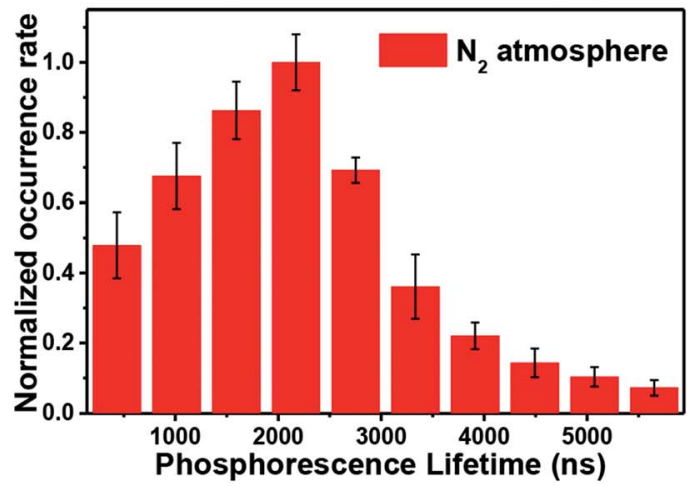

Fig. 3 PLIM of HeLa cell incubated in $50 \mu \mathrm{M}$ of $\operatorname{Ir} 1^{*}$ in the condition of Standard $\mathrm{O}_{2}$ atmosphere (a-c) and $\mathrm{N}_{2}$ atmosphere (d-f). Bright field images ( $a$ and d); PLIM mapping ( $b$ and e); the corresponding phosphorescence lifetime distribution (c and f). Excitation wavelength: $720 \mathrm{~nm}$. The scale bar: $20 \mu \mathrm{m}$.

In this study we found that Ir1* shows detectable phosphorescence in tumor tissue upon local injection, whereas after intravenous administration of Ir ${ }^{*}$ in the same dose $(75 \mathrm{mg}$ $\mathrm{kg}^{-1}$ ) tumor uptake was insufficient for the phosphorescence detection using available technique. It is important to mention

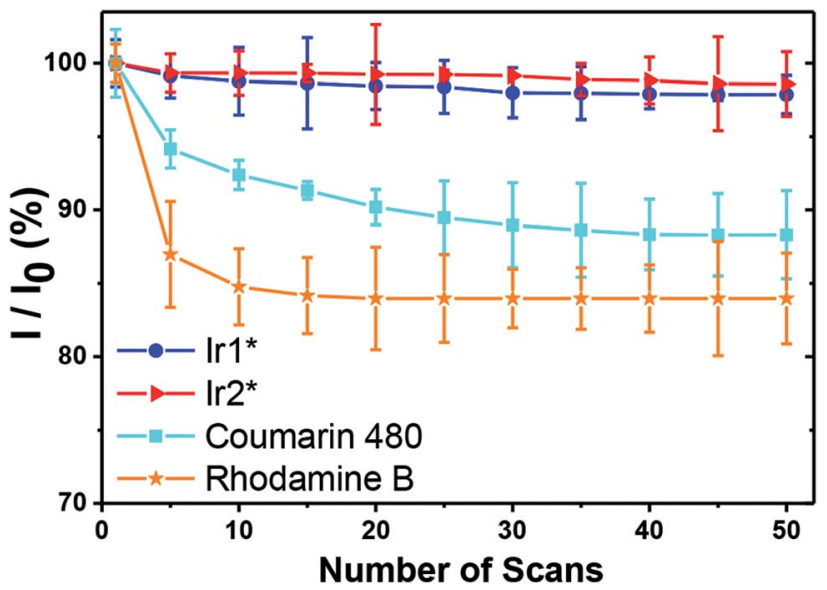

Fig. 4 Photostability plot of Ir1* and Ir2* compared with common luminophores, coumarin 480 (C480) and rhodamine B. Experimental conditions: $10 \mathrm{mM}$ PBS buffer ( $\mathrm{pH} 7.4$ ); all the absorbances are fixed to 0.05 at $360 \mathrm{~nm}$ (Ir1* and C480, $\lambda_{\text {exc }}=720 \mathrm{~nm}$ ) or at $430 \mathrm{~nm}$ (Ir2* and rhodamine $B, \lambda_{\text {exc }}=860 \mathrm{~nm}$ ). Excitation power was $32 \mathrm{~mW}$. I is the emission intensity of each particular scan, and $\mathrm{I}_{0}$ is the emission intensity of the first scan. that no acute toxicity effects were observed in mice neither after local, nor after systemic administration of the probe. Examples of phosphorescence lifetime image of the tumor and the phosphorescence decay curve are shown in Fig. 5. The tumor areas had phosphorescence lifetimes $2590 \pm 60 \mathrm{~ns}$. In the muscle, the phosphorescence lifetime was $2410 \pm 70$ ns (Fig. S42†). The phosphorescence decay curves were fitted with a singleexponential decay mode with an average goodness of fit of less than 1.2. The average number of the analysed photons per curve were not less than 5000. Slightly longer phosphorescence lifetime in the tumor $(p<0.001)$ was, likely, due to reduced level of oxygenation as compared to muscle tissue. Reduced tumor oxygenation compared to surrounding normal tissue (muscle) was previously demonstrated in vivo using PLIM and $\mathrm{O}_{2}$-sensors for different subcutaneous mouse tumor models. ${ }^{23}$

After PLIM, the tumors were examined in vivo on confocal laser scanning microscope to analyze distribution of the probe at the microscopic level (Fig. 5d-f). It was revealed that intratumoral administration of Ir1* resulted in cellular internalization of the dye and staining of the cell cytoplasm along with connective tissue (collagen). A parallel detection of the emission spectra (the lambda scan) confirmed the accumulation of Ir1* in the tissue. Measurements made for control tumor without an injection of Ir1* did not show any phosphorescence signal.

Meanwhile, the phosphorescence lifetimes recorded in the tissue were generally longer than the values in solutions and in cultured HeLa cells. Besides oxygen concentration, some other factors are supposed to affect the phosphorescence lifetimes 

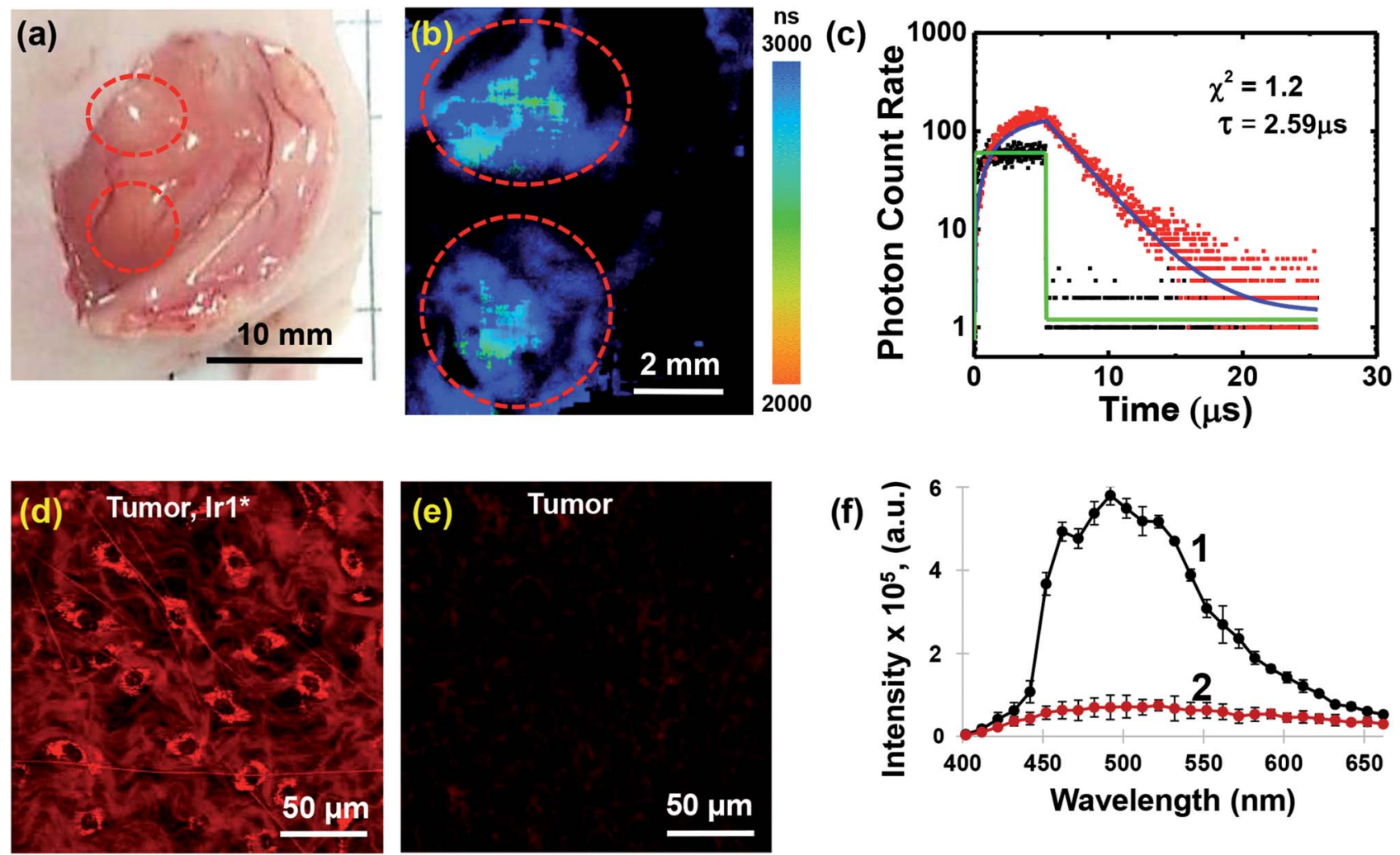

(f)

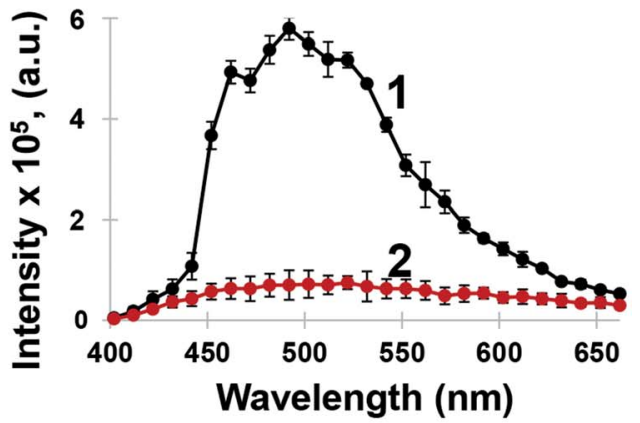

Fig. 5 In vivo imaging of Ir1* phosphorescence in HeLa tumor xenograft. (a) Photograph of HeLa tumor in nu/nu mouse with surgically opened skin flap; (b) PLIM of tumor in vivo after local injection of Ir1*; (c) phosphorescence decay of Ir1* in tumor (red) and signal from control tumor without injection Ir1* in the selected spot in the tumor (black); (d) in vivo confocal laser-scanning microscopy of tumor with Ir1* (ex. 750 nm, reg. 430-600 nm); (e) in vivo microscopic image of the control tumor without injection of Ir1*; (f) emission spectra (ex. $750 \mathrm{~nm}$, reg. $400-662 \mathrm{~nm}$ ) of tumor with local injection Ir1* (1) and of control tumor without injection Ir1* (2), mean \pm SD. Two tumor nodules that were injected with Ir1* are shown by the red dashed circles. Scale bars are indicated in each image. Blue curve on (c) is single exponential fit, green curve is instrument response function.

of oxygen sensitive probes, e.g. binding to proteins, temperature, $\mathrm{pH}$. To estimate the effect of the protein binding, we performed additional PLIM measurements of Ir1* in distilled water and in the presence of $10 \%$ fetal bovine serum (Table $\mathrm{S} 4 \dagger)$. We found that the presence of the serum proteins does not result in considerable change of the phosphorescence lifetimes. Consequently, interaction with proteins cannot be the reason for elongation of the phosphorescence lifetimes in living tissue. To convert the PLIM map into oxygen map, intracellular calibration of the lifetime vs. oxygen concentration is needed. Nevertheless, these pilot experiments on tumor-bearing mice illustrate the high potential of novel Ir1* complex for in vivo mapping of oxygen level in tissue.

\section{Conclusions}

In conclusion, we present synthesis and photophysical investigation of cyclometalated water-soluble $\mathrm{Pt}(\mathrm{II})$ and $\operatorname{Ir}(\mathrm{III})$ complexes containing auxiliary sulfonated diphosphine (bis(diphenylphosphino)benzene (dppb), $\left.\mathrm{P}^{\wedge} \mathrm{P}^{*}\right)$ ligand. The complexes demonstrate considerable variations in excitation (extending up to $450 \mathrm{~nm}$ ) and emission band wavelengths (maxima ranging from $c a$. 450 to $c a$. $650 \mathrm{~nm}$ ), as well as in sensitivity of excited-state lifetimes to molecular oxygen, from almost negligible to more than 4 -fold increase in degassed solution. Moreover, all the complexes possess high twophoton absorption cross sections (400-500 GM for Pt complexes, and 600-700 GM for Ir complexes).

Despite their negative net charge, all these complexes demonstrate good uptake by HeLa cells and low cytotoxicity within the concentration and time ranges suitable for twophoton phosphorescence lifetime (PLIM) microscopy. The most promising complex, [(ppy $)_{2} \operatorname{Ir}($ sulfo-dppb)] (Ir1*), demonstrates two-fold lifetime changes in HeLa cell incubated under normal and nitrogen atmosphere, correspondingly. Further, in vivo evaluation of Ir1* in athymic nude mice bearing HeLa xenografts did not reveal acute toxicity upon both intravenous administration and topical injection. Finally, Ir1* demonstrated statistically significant difference in lifetimes between normal tissue (muscle) and tumor in whole-body in vivo PLIM imaging. Though the pilot experiments on tumor-bearing mice illustrate the high potential of novel Ir1* complex for in vivo mapping of oxygen level in tissue, improvement of the phosphorescence quantum yield and selectivity of the complex to tumor are desirable, and this work is now in progress. 


\section{Conflicts of interest}

There are no conflicts to declare.

\section{Acknowledgements}

The authors greatly appreciate financial support from the Russian Science Foundation (grant 16-43-03003, synthesis, characterization, and spectroscopic studies; grant 14-15-00646-П, in vivo study) and Ministry of Science and Technology of Taiwan (MOST 1062119-M-002-026-MY3, in vitro experiments). The work was carried out using the core facilities of St. Petersburg State University Research Park (Centre for Magnetic Resonance, Centre for Optical and Laser Materials Research, Centre for Chemical Analysis and Materials Research). The authors are thankful to Prof. Elena Zagaynova and Dr Marina Shirmanova (Institute of Biomedical Technologies, Privolzhskiy Research Medical University) for helpful discussions and valuable suggestions, and to Vasily V. Sivchik (Department of Chemistry, University of Eastern Finland) for the synthesis of 2-(benzofuran-3-yl)pyridine.

\section{Notes and references}

1 M. C. L. Yeung and V. W. W. Yam, Struct. Bonding, 2015, 165, 109-130.

2 K. Y. Zhang, S. Liu, Q. Zhao, F. Li and W. Huang, Struct. Bonding, 2015, 165, 131-180.

3 T. Zou, F. F. Hung, C. Yang and C. M. Che, Struct. Bonding, 2015, 165, 181-203.

4 E. Baggaley, J. A. Weinstein and J. A. G. Williams, Struct. Bonding, 2015, 165, 205-256.

5 M. Mauro, A. Aliprandi, D. Septiadi, N. S. Kehr and L. De Cola, Chem. Soc. Rev., 2014, 43(12), 4144-4166.

6 D. L. Ma, H. Z. He, K. H. Leung, D. S. H. Chan and C. H. Leung, Angew. Chem., Int. Ed., 2013, 7666-7682.

7 R. I. Dmitriev and D. B. Papkovsky, Cell. Mol. Life Sci., 2012, 69(12), 2025-2039.

8 D. L. Ma, V. P. Y. Ma, D. S. H. Chan, K. H. Leung, H. Z. He and C. H. Leung, Coord. Chem. Rev., 2012, 3087-3113.

9 Q. Zhao, C. Huang and F. Li, Chem. Soc. Rev., 2011, 40(5), 2508-2524.

10 K. K.-W. Lo, S. P.-Y. Li and K. Y. Zhang, New J. Chem., 2011, 35(2), 265-287.

11 S. W. Botchway, M. Charnley, J. W. Haycock, A. W. Parker, D. L. Rochester, J. A. Weinstein and J. A. G. Williams, Proc. Natl. Acad. Sci. U. S. A., 2008, 105(42), 16071-16076.

12 E. Baggaley, S. W. Botchway, J. W. Haycock, H. Morris, I. V. Sazanovich, J. A. G. Williams and J. A. Weinstein, Chem. Sci., 2014, 5(3), 879-886.

13 J. Liu, Y. Liu, Q. Liu, C. Li, L. Sun and F. Li, J. Am. Chem. Soc., 2011, 133(39), 15276-15279.

14 G. Li, Y. Chen, J. Wu, L. Ji and H. Chao, Chem. Commun., 2013, 49(20), 2040.

15 W. Wang, Z. Z. Dong, C. Yang, G. Li, Y. C. Tse, C. H. Leung and D. L. Ma, Sens. Actuators, B, 2017, 251, 374-379.

16 W. Wang, K. Vellaisamy, G. Li, C. Wu, C.-N. Ko, C.-H. Leung and D.-L. Ma, Anal. Chem., 2017, 89(21), 11679-11684.
17 K. Vellaisamy, G. Li, C.-N. Ko, H.-J. Zhong, S. Fatima, H.-Y. Kwan, C.-Y. Wong, W.-J. Kwong, W. Tan, C.-H. Leung and D.-L. Ma, Chem. Sci., 2018, 9(5), 1119-1125.

18 C. H. Leung, H. J. Zhong, H. Yang, Z. Cheng, D. S. H. Chan, V. P. Y. Ma, R. Abagyan, C. Y. Wong and D. L. Ma, Angew. Chem., Int. Ed., 2012, 51(36), 9010-9014.

19 X. Zheng, X. Wang, H. Mao, W. Wu, B. Liu and X. Jiang, Nat. Commun., 2015, 6, 5834.

20 T. C. O'Riordan, K. Fitzgerald, G. V. Ponomarev, J. Mackrill, J. Hynes, C. Taylor and D. B. Papkovsky, Am. J. Physiol. Regul. Integr. Comp. Physiol., 2006, 292(4), R1613-R1620.

21 T. Yoshihara, M. Hosaka, M. Terata, K. Ichikawa, S. Murayama, A. Tanaka, M. Mori, H. Itabashi, T. Takeuchi and S. Tobita, Anal. Chem., 2015, 87(5), 2710-2717.

22 J. A. Spencer, F. Ferraro, E. Roussakis, A. Klein, J. Wu, J. M. Runnels, W. Zaher, L. J. Mortensen, C. Alt, R. Turcotte, R. Yusuf, D. Côté, S. A. Vinogradov, D. T. Scadden and C. P. Lin, Nature, 2014, 508(7495), 269273.

23 T. V. Esipova, A. Karagodov, J. Miller, D. F. Wilson, T. M. Busch and S. A. Vinogradov, Anal. Chem., 2011, 83(22), 8756-8765.

24 O. S. Finikova, A. Y. Lebedev, A. Aprelev, T. Troxler, F. Gao, C. Garnacho, S. Muro, R. M. Hochstrasser and S. A. Vinogradov, ChemPhysChem, 2008, 9(12), 1673-1679.

25 R. I. Dmitriev, A. V. Kondrashina, K. Koren, I. Klimant, A. V. Zhdanov, J. M. P. Pakan, K. W. McDermott and D. B. Papkovsky, Biomater. Sci., 2014, 2(6), 853-866.

26 A. L. Harris, Nat. Rev. Cancer, 2002, 2(1), 38-47.

27 P. Vaupel, K. Schlenger, C. Knoop and M. Hockel, Cancer Res., 1991, 51(12), 3316-3322.

28 L. I. Cardenas-Navia, D. Mace, R. A. Richardson, D. F. Wilson, S. Shan and M. W. Dewhirst, Cancer Res., 2008, 68(14), 5812-5819.

29 R. D. Shonat and A. C. Kight, Ann. Biomed. Eng., 2003, 31(9), 1084-1096.

30 J. Yu, A. Ramadeen, A. K. Y. Tsui, X. Hu, L. Zou, D. F. Wilson, T. V. Esipova, S. A. Vinogradov, H. Leong-Poi, N. Zamiri, C. D. Mazer, P. Dorian and G. M. T. Hare, Anaesthesia, 2013, 68(7), 723-735.

31 S. Sakadžić, E. Roussakis, M. A. Yaseen, E. T. Mandeville, V. J. Srinivasan, K. Arai, S. Ruvinskaya, A. Devor, E. H. Lo, S. A. Vinogradov and D. A. Boas, Nat. Methods, 2010, 7(9), 755-759.

32 S. V. Apreleva, D. F. Wilson and S. A. Vinogradov, Appl. Opt., 2006, 45(33), 8547-8559.

33 R. I. Dmitriev, H. M. Ropiak, G. V. Ponomarev, D. V. Yashunsky and D. B. Papkovsky, Bioconjugate Chem., 2011, 22(12), 2507-2518.

34 R. Weissleder, Nat. Biotechnol., 2001, 19(4), 316-317.

35 A. M. Smith, M. C. Mancini and S. Nie, Nat. Nanotechnol., 2009, 4(11), 710-711.

36 L. R. Alrawashdeh, M. P. Cronin, C. E. Woodward, A. I. Day and L. Wallace, Inorg. Chem., 2016, 55(13), 6759-6769.

37 K. K. W. Lo, T. K. M. Lee, J. S. Y. Lau, W. L. Poon and S. H. Cheng, Inorg. Chem., 2008, 47(1), 200-208. 
38 D. L. Ma, W. L. Wong, W. H. Chung, F. Y. Chan, P. K. So, T. S. Lai, Z. Y. Zhou, Y. C. Leung and K. Y. Wong, Angew. Chem., Int. Ed., 2008, 47(20), 3735-3739.

39 C. Li, M. Yu, Y. Sun, Y. Wu, C. Huang and F. Li, J. Am. Chem. Soc., 2011, 133(29), 11231-11239.

40 A. Baschieri, S. Muzzioli, V. Fiorini, E. Matteucci, M. Massi, L. Sambri and S. Stagni, Organometallics, 2014, 33(21), 61546164.

41 A. I. Solomatina, P. S. Chelushkin, D. V. Krupenya, I. S. Podkorytov, T. O. Artamonova, V. V. Sizov, A. S. Melnikov, V. V. Gurzhiy, E. I. Koshel, V. I. Shcheslavskiy and S. P. Tunik, Bioconjugate Chem., 2017, 28(2), 426-437.

42 P. K.-M. Siu, D.-L. Ma and C.-M. Che, Chem. Commun., 2005, 1(8), 1025-1027.

43 P. Wu, E. L. M. Wong, D. L. Ma, G. S. M. Tong, K. M. Ng and C. M. Che, Chem.-A Eur. J., 2009, 15(15), 3652-3656.

44 P. S. Chelushkin, D. V. Krupenya, Y.-J. Tseng, T.-Y. Kuo, P.-T. Chou, I. O. Koshevoy, S. V. Burov and S. P. Tunik, Chem. Commun., 2014, 50(7), 849-851.

45 F. Scarpelli, A. Ionescu, L. Ricciardi, P. Plastina, I. Aiello, M. La Deda, A. Crispini, M. Ghedini and N. Godbert, Dalt. Trans., 2016, 45(43), 17264-17273.

46 A. Ionescu, N. Godbert, L. Ricciardi, M. La Deda, I. Aiello, M. Ghedini, I. Rimoldi, E. Cesarotti, G. Facchetti, G. Mazzeo, G. Longhi, S. Abbate and M. Fusè, Inorg. Chim. Acta, 2017, 461, 267-274.

47 H.-J. Yin, Y.-J. Liu, J. Gao and K.-Z. Wang, Dalt. Trans., 2017, 46(10), 3325-3331.

48 A. W.-T. Choi, M.-W. Louie, S. P.-Y. Li, H.-W. Liu, B. T.-N. Chan, T. C.-Y. Lam, A. C.-C. Lin, S.-H. Cheng and K. K.-W. Lo, Inorg. Chem., 2012, 51(24), 13289-13302.

49 Y. Zhu, C. Xu, Y. Wang, Y. Chen, X. Ding and B. Yu, RSC Adv., 2017, 7(52), 32632-32636.

50 W. A. Herrmann and C. W. Kohlpaintner, Angew. Chem., Int. Ed. Engl., 1993, 1524-1544.

51 Y. R. Hristova, B. Kemper and P. Besenius, Tetrahedron, 2013, 69(49), 10525-10533.

52 L.-A. Schaper, S. J. Hock, W. A. Herrmann and F. E. Kühn, Angew. Chem., Int. Ed., 2013, 52(1), 270-289.

53 D. García-Fresnadillo and G. Orellana, Helv. Chim. Acta, 2001, 84(9), 2708-2730.

54 F. F. Hung, W. P. To, J. J. Zhang, C. Ma, W. Y. Wong and C. M. Che, Chem. - A Eur. J., 2014, 20(28), 8604-8614.

55 C. K. Koo, K. L. Wong, C. W. Y. Man, H. L. Tam, S. W. Tsao, K. W. Cheah and M. H. W. Lam, Inorg. Chem., 2009, 48(16), 7501-7503.

56 S. Y. Yin, S. S. Sun, M. Pan, Y. Z. Fan, Y. X. Chen, H. P. Wang and Y. N. Fan, Inorg. Chem. Commun., 2017, 83, 81-83.

57 N. Godbert, T. Pugliese, I. Aiello, A. Bellusci, A. Crispini and M. Ghedini, Eur. J. Inorg. Chem., 2007, 32, 5105-5111.

58 C.-L. Li, Y.-J. Su, Y.-T. Tao, P.-T. Chou, C.-H. Chien, C.-C. Cheng and R.-S. Liu, Adv. Funct. Mater., 2005, 15(3), 387-395.

59 A. M. Brouwer, Pure Appl. Chem., 2011, 83(12), 2213-2228.

60 K. Rurack and M. Spieles, Anal. Chem., 2011, 83(4), 12321242.
61 Bruker, APEX II, Bruker AXS Inc., Madison, Wisconsin, USA, 2013.

62 G. M. Sheldrick, Acta Crystallogr., Sect. C: Struct. Chem., 2015, 71, 3-8.

63 L. J. Farrugia, J. Appl. Crystallogr., 2012, 45(4), 849-854.

64 Bruker, APEX II, Bruker AXS Inc., Madison, Wisconsin, USA, 2009.

65 A. L. Spek, Acta Crystallogr., Sect. D: Biol. Crystallogr., 2009, 65(2), 148-155.

66 V. I. Shcheslavskiy, A. Neubauer, R. Bukowiecki, F. Dinter and W. Becker, Appl. Phys. Lett., 2016, 108(9), 091111.

67 S. Kalinina, J. Breymayer, P. Schäfer, E. Calzia, V. Shcheslavskiy, W. Becker and A. Rück, J. Biophotonics, 2016, 9(8), 800-811.

68 J. A. G. Williams, Top. Curr. Chem., 2007, 281, 205-268.

69 L. Flamigni, A. Barbieri, C. Sabatini, B. Ventura and F. Barigelletti, Top. Curr. Chem., 2007, 281, 143-203.

70 E. C. Constable, C. E. Housecroft, E. Schönhofer, J. Schönle and J. A. Zampese, Polyhedron, 2012, 35(1), 154-160.

71 S. X. Luo, L. Wei, X. H. Zhang, M. H. Lim, K. X. V. Lin, M. H. V. Yeo, W. H. Zhang, Z. P. Liu, D. J. Young and T. S. A. Hor, Organometallics, 2013, 32(10), 2908-2917.

72 L. He, C. P. Tan, R. R. Ye, Y. Z. Zhao, Y. H. Liu, Q. Zhao, L. N. Ji and Z. W. Mao, Angew. Chem., Int. Ed., 2014, 53(45), 12137-12141.

73 M. Sarma, T. Chatterjee, R. Bodapati, K. N. Krishnakanth, S. Hamad, S. Venugopal Rao and S. K. Das, Inorg. Chem., 2016, 55(7), 3530-3540.

74 R. M. Edkins, S. L. Bettington, A. E. Goeta and A. Beeby, Dalt. Trans., 2011, 40(47), 12765-12770.

75 C.-L. Ho, K.-L. Wong, H.-K. Kong, Y.-M. Ho, C. T.-L. Chan, W.-M. Kwok, K. S.-Y. Leung, H.-L. Tam, M. H.-W. Lam, X.-F. Ren, A.-M. Ren, J.-K. Feng and W.-Y. Wong, Chem. Commun., 2012, 48(19), 2525-2527.

76 C.-K. Koo, K.-L. Wong, C. W.-Y. Man, Y.-W. Lam, L. K.-Y. So, H.-L. Tam, S.-W. Tsao, K.-W. Cheah, K.-C. Lau, Y.-Y. Yang, J.-C. Chen and M. H.-W. Lam, Inorg. Chem., 2009, 48(3), 872-878.

77 M. G. Vivas, L. De Boni, T. M. Cooper and C. R. Mendonca, J. Phys. Chem. A, 2014, 118(30), 5608-5613.

78 Z. Ji, Y. Li, T. M. Pritchett, N. S. Makarov, J. E. Haley, Z. Li, M. Drobizhev, A. Rebane and W. Sun, Chemistry, 2011, 17(8), 2479-2491.

79 M. G. Vivas, L. De Boni, T. M. Cooper and C. R. Mendonca, ACS Photonics, 2014, 1(2), 106-113.

80 W. Sun, B. Zhang, Y. Li, T. M. Pritchett, Z. Li and J. E. Haley, Chem. Mater., 2010, 22(23), 6384-6392.

81 G. L. Semenza, Science, 2007, 318(5847), 62-64.

82 S. Liu, H. Liang, K. Y. Zhang, Q. Zhao, X. Zhou, W. Xu and W. Huang, Chem. Commun., 2015, 51(37), 7943-7946.

83 L. Sun, G. Li, X. Chen, Y. Chen, C. Jin, L. Ji and H. Chao, Sci. Rep., 2015, 5, 14837.

84 A. Y. Lebedev, A. V. Cheprakov, S. Sakadzic, D. A. Boas, D. F. Wilson and S. A. Vinogradov, ACS Appl. Mater. Interfaces, 2009, 1(6), 1292-1304. 
85 M. Lepeltier, F. Appaix, Y. Y. Liao, F. Dumur, J. Marrot, T. Le Bahers, C. Andraud and C. Monnereau, Inorg. Chem., 2016, 55(19), 9586-9595.
86 C. Jin, J. Liu, Y. Chen, L. Zeng, R. Guan, C. Ouyang, L. Ji and H. Chao, Chem.-A Eur. J., 2015, 21(34), 12000-12010. 